Article

\title{
How Do Women Managers Avoid Paying Bribes?
}

\author{
George R. G. Clarke (1)
}

check for

updates

Citation: Clarke, George R. G.. 2021. How Do Women Managers Avoid Paying Bribes?. Economies 9: 19. https://doi.org/10.3390/economies 9010019

Academic Editor:

Aleksander Panasiuk

Received: 29 December 2020

Accepted: 1 February 2021

Published: 4 February 2021

Publisher's Note: MDPI stays neutral with regard to jurisdictional claims in published maps and institutional affiliations.

Copyright: (C) 2021 by the author. Licensee MDPI, Basel, Switzerland. This article is an open access article distributed under the terms and conditions of the Creative Commons Attribution (CC BY) license (https:/ / creativecommons.org/licenses/by/ $4.0 /)$.
Division of International Banking and Finance Studies, A.R. Sanchez, Jr. School of Business, Texas A\&M In-ternational University, Laredo, TX 78041, USA; george.clarke@tamiu.edu

\begin{abstract}
Previous studies have found that firms where women have greater influence are less likely to pay bribes than other firms. In this study, we ask how these firms avoid paying bribes. Using data from the World Bank's Enterprise Surveys, we find that firms run by women avoid meeting and interacting with government officials when they can. Female-managed firms, for example, are less likely to apply for construction and import licenses, less likely to meet with tax officials, and less likely to bid for government contracts than male-managed firms. However, female-managed firms are no less likely to say that officials sought bribes when they met with them than male-managed firms. This suggests the main way that firms with women in positions of power avoid paying bribes is by avoiding situations where officials might seek them.
\end{abstract}

Keywords: corruption; bribes; firm behavior; enterprise surveys

\section{Introduction}

Corruption is a less severe problem in countries with greater female participation in government and the workforce (Dollar et al. 2001; Swamy et al. 2001). Although this might be because women reject corruption more forcefully than men, correlation does not imply causation. Later studies found the relationship becomes insignificant after controlling for culture and democratic rights (Debski et al. 2018; Goetz 2007; Sung 2003). Misgivings about the link did not, however, stop governments from trying to exploit it. Lima's traffic police became all-female in 1998, and the Mexican Customs Service announced an all-female anti-corruption force in 2003 (Goetz 2007).

Country-level studies, however, do not provide the only evidence on gender and corruption. Observational studies using individual-level data have found corruption troubles women more than men and that officials ask women for bribes less often than men (Mocan 2008; Swamy et al. 2001). Further, experimental evidence from laboratory-based corruption games often, but not always, find female participants are less likely to pay bribes than male participants (Frank et al. 2011).

Even if women are less likely to pay bribes than men, women managers and entrepreneurs might need to behave differently from other women. Women managers and owners who snub demands for bribes might find government agencies refuse to provide them with essential services, required licenses and permits, or contracts. To survive in an environment rife with corruption, women in leadership positions might have to pay bribes as often as similar men. In practice, however, they do not. Studies have found that women managers and entrepreneurs are less likely to pay bribes than men (Breen et al. 2017; Swamy et al. 2001).

So how can women managers and entrepreneurs sidestep bribe demands? One way is to avoid interacting with government officials. Firms could ignore government rules by remaining wholly or partly informal. They could also refuse to engage in avoidable transactions. For example, firms could focus on private, rather than government, contracts. Finally, firms could hire agents to meet with officials and apply for licenses for them. For example, firms could hire contractors to build new offices or warehouses to avoid dealing with building inspectors and obtaining construction licenses. 
Another way to avoid paying bribes is not to offer them or even to refuse to pay when officials demand them. Rebuffing bribe requests will make meetings with officials more difficult. The firm might find it challenging to secure licenses, deal with inspections, and win government contracts. Firms that refuse to pay bribes, however, might complete many tasks eventually. When setting up a garment factory in Peru, ten officials asked de Soto's research team for bribes (de Soto 1988). The team, however, only paid twice. In other cases, firms might be able to appeal to high-level officials if their corrupt subordinates deny their applications or mistreat them.

Using data from the World Bank's Enterprise Surveys, we look at how firms with women decision-makers avoid paying bribes. Because the survey includes separate questions about whether the firm engages with government officials and whether they paid bribes when they did, we can use the data to test two separate hypotheses. We first look at whether women managers and entrepreneurs avoid meeting with government officials, and we then look at whether they are less likely to pay bribes when they do meet with them.

Section 2 of the paper describes earlier studies related to corruption and gender, discusses reasons why women might be less likely to pay bribes, and presents several hypotheses related to corruption and gender. Section 3 describes the data and the econometric model. Section 4 presents the results and Section 5 concludes.

\section{Literature Survey and Hypotheses}

In this section, we review results from existing work on gender and corruption. We first survey the three types of evidence on women and corruption: country-level studies; firm and individual level observational studies; and experimental studies. We then discuss some possible explanations for the empirical results. Finally, we develop several hypotheses that we will test in the paper's empirical section.

\subsection{Are Women Less Corrupt than Men?}

Although not conclusive, much evidence suggests women are more averse to giving and receiving bribes than men. The best-known results come from cross-country studies; countries with more women in government and the labor force are less corrupt than other countries (Dollar et al. 2001; Swamy et al. 2001). Women being less corrupt than men could explain the relationship. Sung (2003), however, argues other factors might play a role, suggesting liberal democracies both promote gender equality and are less corrupt. After controlling for democratic institutions, the association becomes insignificant (Sung 2003). Similarly, Debski et al. (2018) show the correlation also becomes insignificant after controlling for two of Hofstede's (1984) measures of culture.

Other evidence also supports the country-level results; studies using individual-level data have also found women are more averse to bribes than men. First, women are less likely to say taking bribes is acceptable than men (Swamy et al. 2001; Torgler and Valev 2010). Second, people believe women are less corrupt than men. Both male and female students in Spain, for example, agreed female public officials are less likely to take bribes than male officials (Rivas 2013). Similarly, taxi drivers in Colombia claimed female transit officers accept bribes less often than male officers (Graf Lambsdorff and Fink 2006). Third, fewer women than men report they have engaged in corrupt acts. Mocan (2008) finds women are less likely to say officials have asked them for bribes than men.

Experimental studies also support the idea that women are more averse to corruption than men. In these experiments, one player, who acts as the firm, can bribe another player, who acts as a public official, to win a contract or earn a higher return on their investment. If the person acting as the public official accepts the bribe, this harms a third party. Some games allow the person playing the official to accept the bribe but not award the contract to the bribe giver. Some also randomly reduce the payments to players who give or receive bribes to simulate the authorities detecting and punishing corrupt officials. Some studies find female players are less likely to offer bribes or offer lower bribes than male players 
(Alatas et al. 2009; Rivas 2013). In contrast, most studies do not find significant differences between the men and women who play the officials taking bribes (Frank et al. 2011).

The results from experimental and individual-level studies suggest women might tolerate corruption less than men. One concern, however, for firm-level studies is women managers might not behave like other women. Discussing the experimental evidence on corruption, Frank et al. (2011, p. 68) argue:

Do these results hold for real decision-makers in the real world? For instance, this would not be the case if women in the highest positions behave, owing to indoctrination or self-selection, like men in every relevant aspect. Women's resistance towards corruption may disappear if their career forces them to engage in reciprocal exchange.

Even if the average woman were less corrupt than the average man, high-level women managers or government officials might behave differently from other women.

Although this is possible, studies do not support the idea that high-level women managers behave like similar men. Swamy et al. (2001) found female managers in the exSoviet Republic of Georgia reported paying bribes less often than male managers. Similarly, Breen et al. (2017) found firms with female owners were less likely to pay bribes or to say corruption was a serious problem than firms with male owners. Overall, these results suggest female-led firms are less likely to pay bribes than male-led firms.

\subsection{Why Are Women Less Corrupt than Men?}

Evidence from cross-country, individual-level, and experimental studies suggest women are less likely to engage in corrupt acts than men. Women's lower propensity to give and receive bribes might reflect their lower propensity to commit any crime. About 270 men were arrested in the United States for every 100 women in 2017 (Federal Bureau of Investigations 2018). American men are also more likely to admit they have committed crimes than American women (Britton et al. 2018). Similar patterns hold in other countries. In a study covering 53 countries, men committed about 92 percent of homicides (United Nations Office on Drugs and Crime 2013). Moreover, women make up fewer than onequarter of prisoners in every country with available data (Walmsley 2017).

Even if women's lower propensity to bribe reflects their lower propensity to commit any crime, this just leads us to ask why women commit fewer crimes than men. One possibility is that it is because women are more ethical or socially responsible than men. This might also make women less inclined to pay bribes; most people believe taking bribes is wrong (Swamy et al. 2001).

Although ethics might explain women's lower predilection to give and receive bribes, some researchers have questioned whether women are more ethical than men. Only about half of empirical studies of ethics find significant differences between men and women, although those studies with significant differences find women are more ethical (O'Fallon and Butterfield 2005). Further, most studies that compare men's and women's ethics rely on self-reported information. If social desirability bias affects women's answers more than men's, this could explain why women are less likely to report unethical behavior (Bossuyt and Van Kenhove 2018).

Social orientation might also affect men's and women's relative inclinations to pay bribes and commit crimes. Experimental studies, however, do not support the idea that women are more socially oriented than men (Croson and Gneezy 2009; Shurchkov and Eckel 2018). Results for altruism, cooperation, trust, and willingness to contribute to public goods are inconclusive (Croson and Gneezy 2009; Shurchkov and Eckel 2018).

A second possibility is women might be unwilling to become involved in corrupt acts-and possibly other crimes-because they are more risk-averse than men. Because offering and demanding bribes is often illegal, doing so might create problems for anyone who does. Further, bribe payers cannot be sure corrupt officials will deliver promised goods and services. If officials fail to do so, people paying bribes have no legal recourse. Someone who is risk-averse might, therefore, be wary about advancing or accepting bribes. If women, on average, are more risk-averse than men-and some experimental and observational 
studies suggest they might be (Croson and Gneezy 2009; Shurchkov and Eckel 2018)—-they might be more reluctant to pay bribes.

Even if women, on average, dislike risk more than men, women who enter careers that require them to take risks might be different from other women. Consistent with this idea, women managers and women in careers that encourage risky behavior are not much more risk-averse than similar men (Croson and Gneezy 2009). Becoming an entrepreneur or high-level manager in a corrupt country might only appeal to risk-loving women.

A third possibility is women might avoid paying bribes because they dislike negotiating bribe payments more than men. In a literature survey of gender differences in labor markets, Shurchkov and Eckel (2018, p. 495) argue that observational studies, laboratory experiments, and field experiments support the idea that "women shy away from negotiations." Given bribe payers and takers must haggle over how much to pay, people who dislike wheeling and dealing might be unwilling to offer bribes. Once again, however, women managers might not behave like other women — only people willing to bargain might self-select into management roles that require them to do so.

A final possibility is women might not pay bribes as often as men in some countries because these countries have biased social structures that mean they are not connected well enough to do so. Officials might be averse to accepting bribes from people whom they do not know - especially when they need to provide favors in return. Meeting, socializing, and building relationships with bribe-taking officials is, therefore, essential. Ufere et al. (2012) discuss how connectors-often ex-politicians or ex-military officials-help entrepreneurs in Nigeria to pay bribes by introducing them to government officials and providing them with legitimacy. If women, on average, have fewer connections than men, they might find it harder to pay bribes.

In summary, women might be less willing than men to pay bribes for several different reasons. They might be more ethical or socially responsible. They might be more riskaverse. They might be unwilling to negotiate bribe payments. Or they might lack the contacts they need to access corrupt networks.

\subsection{Hypotheses}

One way that women could circumvent bribe requests would be to avoid corrupt officials whenever they can. For example, managers can avoid paying bribes for government contracts by not bidding for them. Similarly, they can avoid getting some licenses by adopting alternative strategies. For example, they might choose to buy or lease existing properties, so they do not need construction licenses. They might also remain partly informal; something many firms - even formal ones-do in developing countries (Shah 2012). Finally, firms might hire agents to navigate the bureaucracy on their behalf and, in so doing, avoid the need to pay bribes themselves. Looking at people applying for driver's licenses in India, for example, Bertrand et al. (2007, p. 1641) find "no evidence of direct payments to bureaucrats ... extralegal payments are mainly fees to 'agents', professionals who assist individuals in the process of obtaining their driver's licenses." Our first hypothesis is, therefore:

Hypothesis 1. Firms with women in positions of power will be less likely to interact with government officials than other firms.

Women might also avoid paying bribes by not offering bribes to corrupt officials. Women might do so because they dislike negotiating the amount, do not have personal relationships with the officials they need to bribe, or are more ethical than men. They might also do so because they are risk-averse; if they are unsure whether the official will report them, they might not risk trying to bribe the official. This leads to our second hypothesis.

Hypothesis 2. When firms with women in positions of power interact with government officials, they will be less likely to pay bribes than other firms. 
Although women might not offer bribes for the reasons discussed above, only some might make them more likely to refuse to pay when officials demand bribes. If they do not offer bribes mostly because they believe it is wrong, they should also refuse to pay when officials demand bribes. However, being risk-averse might not affect their behavior in the same way; refusing to pay might be riskier than complying. Similarly, paying the bribe might reduce, rather than increase, the time spent negotiating with corrupt officials. Finally, poorly connected people might be more, not less, vulnerable to bribe demands. Well-connected managers might be able to appeal to high-level officials when low-level bureaucrats ask them for money.

\section{Methodology and Materials}

This section describes the data that we use to test the previous section's hypotheses. Testing the first hypothesis is straightforward with data from the World Bank Enterprise Surveys (WBES). In contrast, it is harder to test the second hypothesis. To allow the respondent to answer questions about corruption without admitting they pay bribes, the survey only includes indirect questions about bribe payments. Because the questions do not directly ask whether the respondents paid bribes, interpreting their answers is difficult.

\subsection{Data}

This paper uses firm-level data from the WBES. The surveys cover private, formal firms with at least five workers in retail and wholesale trade, manufacturing, and other services. They exclude microenterprises and fully, but not partly, government-owned firms. Because government agencies provide the lists for the sampling frame, the sample excludes unregistered firms. The surveys include questions about the firm's experience with regulation and corruption.

Although the WBES program started in the early 2000s-and the World Bank standardized the questionnaire in 2006 - the survey did not include questions on gender until 2008. We, therefore, can only use these later surveys. The resulting dataset is large; it includes over 100,000 firms from 200 surveys in 133 countries (see Table S1 in the Supplementary Materials).

\subsection{Questions of Corruption}

The WBES includes several questions about corruption. We focus on questions about bribes paid during specific transactions because these allow us to address the hypotheses listed above. The survey asks whether firms have applied for specific licenses, whether tax officials have inspected or visited them, and whether they have tried to secure government contracts. For each transaction, the survey asks whether the official sought a bribe. For example, the questions about import licenses are:

Over the last two years, did this establishment submit an application to obtain an import license? (World Bank 2007)

And:

In reference to that application for an import license, was an informal gift or payment expected or requested? (World Bank 2007)

The questions ask about the manager's experiences. As a result, we can interpret their answers more easily than answers to indirect questions like "do firms usually pay bribes during these transactions". Although the questions ask about firms' experiences, managers can answer without incriminating themselves; the manager might have refused to pay.

The question does, however, have two weaknesses. The main one is we do not know whether the manager paid a bribe. If, for example, we found female managers answered "yes" more often than male managers, this does not mean women pay more bribes than men. Even if officials ask female managers for bribes more often than they ask male managers, women might refuse to pay them more often than men. 
The question's second weakness is we do not know who proposed the bribe. If government officials believe, on average, women dislike negotiating more than men, they may demand more bribes from women than they do from men thinking women will not argue. However, women might offer fewer bribes then men if, on average, women dislike negotiating more than men. If we knew who proposed the bribe, we could better distinguish between the different explanations for the relationship between gender and corruption.

The survey also asks whether the firm has sought government contracts within the past year. Unlike the previous questions, the survey does not ask about the firm's experience. Instead, it asks whether firms typically pay bribes when seeking contracts. The questions are:

Over the last 12 months, has this establishment secured a government contract or attempted to secure a contract with the government? (World Bank 2007)

If the manager attempted to secure a contract, he or she is asked:

When establishments like this one do business with the government, what percent of the contract value would typically be paid in informal payments or gifts to secure the contract (World Bank 2007)

A manager who refuses to pay bribes might answer that firms typically pay bribes if they believe other managers do. In practice, however, when researchers use indirect questions about corruption, they usually assume the person answers thinking about their own experiences rather than about what others do (Clarke and Xu 2004; Johnson et al. 2002; Svensson 2003). We can justify this in two ways. First, managers might recognize that the interviewer wants to know what they do, despite the indirect wording (Johnson et al. 2002). Even if they do not work out what the interviewer wants, managers who pay bribes might believe other managers are also corrupt. Previous studies have found a false consensus effect: people think others act and think like them (Ross et al. 1977). The question, however, has one advantage; it asks about bribes paid rather than sought and, therefore, complements the earlier questions.

\subsection{Questions of Female Decision-Makers}

The WBES focuses on what the firm, not the firm's manager or owner, does. We can, therefore, only use WBES data to see how gender affects behavior when women can change firm behavior. We expect women to affect whether the firm pays bribes when women play decision-making roles within the firm.

The WBES includes three questions on the gender of the firm's decision-makers. The first asks whether the firm's top manager is a woman. Although the top manager might not dictate all critical decisions-lower-level managers and shareholders will also play a role-we expect the top manager to influence how the firm does business.

The second provides information on the firm's owners. Because individual owners might have little influence when ownership is diverse, we focus on fully female-owned firms. When the principal owner is also the top manager, we would expect them to affect firm decisions. Even when a professional manager runs the firm, the owner might influence firm behavior indirectly.

The third describes the gender of the person responding to the survey. Unlike the previous questions, the respondent might not have much influence over firm behavior. In theory, the respondent should be the person who represents "the firm for official purposes, that is the individual who most often deals with banks or government agencies/institutions" (World Bank 2006). In practice, however, a wide range of managers and professional staff, including chief financial officers, chief operating officers, plant managers, sales managers, accountants, and other managers and professional staff, answer the survey. Although the respondent plays some management or administrative role, they are not always the principal decision-maker. Information about the respondent might, however, remain use- 
ful. Female respondents will probably be more common, and women will have greater influence, in firms where more women have decision-making roles.

Female respondents, however, might affect the answer in another way. Respondents often do not tell the truth when answering sensitive questions about topics like corruption (Azfar and Murrell 2009). Different respondents at the same firm might, therefore, answer sensitive questions differently. If gender affects how respondents answer sensitive questions, the respondent might affect the answer without affecting the firm's behavior.

In practice, the three dummies are highly correlated (see Table 1). Female-owned firms are more likely to have women managers and respondents than other firms. Similarly, female-managed firms are also more likely to have female respondents. However, not all female respondents worked for female-owned or -managed firms; more worked for malemanaged than female-managed firms (12,563 versus 10,630$)$. This is not inconsistent with a positive correlation; firms were five times more likely to have male than female managers. Similarly, more female managers work for male-owned, rather than female-owned, firms (6171 versus 3906).

Table 1. Correlations of female managers, owners, and respondents.

\begin{tabular}{cccc}
\hline & $\begin{array}{c}\text { Manager Is a } \\
\text { Woman }\end{array}$ & $\begin{array}{c}\text { All Owners Are } \\
\text { Women }\end{array}$ & $\begin{array}{c}\text { Respondent Is a } \\
\text { Woman }\end{array}$ \\
\hline Manager is a woman & 1.000 & & \\
All owners are women & $0.471^{* * *}$ & 1.000 & \\
& $(0.00)$ & $0.328^{* * *}$ & 1.000 \\
Respondent is a woman & $\begin{array}{c}0.461^{* * *} \\
(0.00)\end{array}$ & $(0.00)$ & \\
\hline
\end{tabular}

Source: Authors' calculation based upon data from the World Bank Enterprise Surveys. ${ }^{* * *}$ Statistically Significant at $1 \%$ significance levels. Note: $P$-values in parentheses.

\subsection{Descriptive Statistics}

As well as asking about bribe payments and government transactions, the survey also asks about the firm's ownership, size, export status, and industry. Because these might also affect transactions or bribes, the analysis controls for them. A table in the online Supplementary Materials includes summary statistics (see Table S2).

Female-managed firms were less likely to try to get construction and import licenses, meet with tax officials, and bid for government contracts than male-managed firms (see Table 2). The differences are statistically significant, supporting the first hypothesis that women are less likely to bribe officials than men because they avoid meeting with them. The exception is operating licenses; female-managed firms were more, not less, likely to apply for operating licenses than male-managed firms. One possibility is that, in contrast to other licenses and government contracts, large firms cannot avoid getting operating licenses.

In contrast, the pattern for bribes was inconsistent. Female-managed firms were more likely to say officials sought bribes when they applied for import licenses, but the opposite was true for operating licenses and meetings with tax officials. The differences between male and female managers were insignificant for construction licenses and government contracts.

Female-managed firms are also different in other ways (see Table 3). On average, they are smaller ( 85 and 121 workers), less likely to export (20 and 23 percent), less likely to have foreign owners ( 6 and 8 percent), and more likely to be in the retail trade industry (36 and 27 percent) than other firms. Per capita income is also higher in countries with more female-managed firms. If these characteristics affect how likely firms are to pay bribes or interact with government officials, this could explain why firms with male and female managers have different propensities to meet and bribe officials. In the next section, we explore transactions and corruption controlling for these other differences. 
Table 2. Sample means for dependent variables for male and female managers.

\begin{tabular}{cccc}
\hline & Men & Women & Significance \\
\hline Got construction license & $13.9 \%$ & $12.2 \%$ & $* * *$ \\
Got import license & $12.8 \%$ & $9.7 \%$ & $* * *$ \\
Got operating license & $22.9 \%$ & $24.4 \%$ & $* * *$ \\
Tax inspection & $59.6 \%$ & $53.8 \%$ & $* * *$ \\
Bid for government contract & $18.5 \%$ & $14.8 \%$ & \\
Bribes for construction license & $20.3 \%$ & $20.1 \%$ & $* * *$ \\
Bribes for import license & $11.1 \%$ & $13.6 \%$ & $* *$ \\
Bribes for operating license & $14.5 \%$ & $13.1 \%$ & $* *$ \\
Bribes for tax officials & $13.3 \%$ & $12.4 \%$ & \\
Bribes for government contracts & $14.8 \%$ & $16.0 \%$ & $*$
\end{tabular}

Source: Authors' calculation based upon data from the World Bank Enterprise Surveys. ${ }^{* * *},{ }^{* *}$ Statistically Significant at $1 \%$ and $5 \%$ significance levels (two-sided $t$-test).

Table 3. Sample means for independent variables for male and female managers.

\begin{tabular}{cccc}
\hline & Men & Women & Significance \\
\hline \# of workers & 121 & 85 & $* * *$ \\
Firm exports & $23.0 \%$ & $19.8 \%$ & $* * *$ \\
Percentage foreign-owned & 7.9 & 6.2 & $* * *$ \\
Percentage government-owned & 0.7 & 0.6 & $* * *$ \\
Per capita GDP & $\$ 9939$ & $\$ 10,922$ & $* * *$ \\
Firm is in manufacturing & $55.1 \%$ & $46.8 \%$ & $* * *$ \\
Firm is in retail trade & $27.0 \%$ & $35.8 \%$ & $*$ \\
Firm is in other services & $18.0 \%$ & $17.4 \%$ & $*$
\end{tabular}

Source: Authors' calculation based upon data from the World Bank Enterprise Surveys. ${ }^{* * *},{ }^{*}$ Statistically Significant at $1 \%$ and $10 \%$ significance levels (two-sided $t$-test).

\subsection{Econometric Model}

To explore why female managers are less likely to pay bribes than male managers, we look at how likely they are to meet with officials and how likely officials are to seek bribes during those meetings. Female managers might avoid paying bribes by dodging meetings with corrupt officials (H1). Alternatively, they might refuse to offer or pay bribes to officials when they do meet with them (H2).

We test the first hypothesis by regressing dummies showing whether managers have recently met with different government agencies on a dummy showing the manager is a woman and some controls. These meetings include applying for construction, operating and import licenses, meeting with tax officials, and trying to secure government contracts. We assume the likelihood the manager meets with government officials is:

$$
\text { Propensity } \text { to interact }_{i j}=\alpha_{j}+\beta \text { Female }_{i j}+\gamma x_{i j}+\varepsilon_{i j}
$$

We do not, however, see the firm's propensity to meet with officials. We, therefore, assume the firm does so if its propensity exceeds some critical level, which we can normalize to zero. That is:

$$
\text { Interaction }_{i j}=\left\{\begin{array}{lll}
1 & \text { if } & \text { Propensity } \\
0 & \text { if } & >0 \\
\text { Propensity } & \leq 0
\end{array}\right.
$$

We assume that the error term has a normal distribution and, therefore, estimate the model as a Probit model.

The regression includes several controls. First, we include per capita GDP to control for country-level institutions. Firms might be more likely to pay bribes in countries with weak governance. If fewer people pay bribes and more firms have women managers in countries with stronger institutions, as Sung (2003) suggests, we might find a spurious relationship between the two if we fail to control for institutions. As a robustness check, we include country dummies. 
Second, we include several firm-level controls. These include controls for the firms' size, ownership, and industry. Large firms and partly government-owned firms, for example, might pay fewer bribes if these firms' managers know more high-level government officials or if they can lobby government more effectively than small firms. However, they might meet with officials more frequently because they cannot hide as easily. Foreignowned firms might refuse to pay bribes because they worry about bad publicity or even prosecution if their home government catches them paying bribes. On the other hand, officials might target them if the officials believe they can pay more. Exporters might deal with officials, especially in the customs administration, more often than non-exporters. Finally, governments regulate different industries in distinct ways, meaning opportunities for bribes will vary across sectors.

Unlike the first hypothesis, which we can easily test with data from the WBES, it is difficult to directly test the second hypothesis. The problem is the question does not ask whether the manager paid, or offered to pay, a bribe. Instead, it asks whether an official sought or expected a bribe. Managers who answer "yes" might have refused to pay. Similarly, managers who answer "no" might have offered to pay, or even paid, a bribe. As an imperfect test of the second hypothesis, we regress the likelihood that officials sought or expected bribes on a dummy signaling the manager is a woman and the other controls. The model is therefore:

$$
\text { Likelihood of having bribes requested }_{i j}=\alpha_{j}+\beta \text { Manager } \quad \text { is Female } e_{i j}+\gamma x_{i j}+\xi_{i j}
$$

Because we cannot observe the likelihood, we estimate the model with a dummy variable that is equal to:

$$
\text { Bribe requested }_{i j}=\left\{\begin{array}{l}
1 \text { if Propensity } \\
0 \text { if }>0 \\
\text { if Propensity } \\
i j
\end{array}\right.
$$

Estimating the second equation is challenging. The main problem is only firms that met with officials were asked whether officials sought bribes, resulting in a selection problem. If the likelihood that officials seek bribes is different for firms that met with officials and firms that did not, the second regression's coefficients will be inconsistent.

We, therefore, estimate the two equations as a bivariate probit model that allows for selection effects. To make it easier to identify the system, we include an extra variable in the first equation: the percentage of other firms in the same city that met with officials for similar purposes. Rules about licenses, tax inspections, and government contracts vary across regions within and between countries. The percentage of other firms that meet with officials is a proxy for the region's regulatory burden. The proxy's coefficients are significant in the transaction regressions, suggesting they work well.

\section{Results}

Table 4 shows results for the entire sample for female-managed firms. These regressions include a dummy signaling the firm's top manager was a woman. In later tables, we show results for female-owned firms and firms with female respondents. We also present results from separate regressions for highly corrupt and less corrupt countries and perform some robustness checks. 
Table 4. Probability firms engage with government and bribe was requested, woman manager.

\begin{tabular}{|c|c|c|c|c|c|c|}
\hline License/gov't Interaction & \multicolumn{2}{|c|}{ Construction License } & \multicolumn{2}{|c|}{ Import License } & \multicolumn{2}{|c|}{ Sales to Government } \\
\hline Total observations & \multicolumn{2}{|c|}{100,600} & \multicolumn{2}{|c|}{100,118} & \multicolumn{2}{|c|}{99,572} \\
\hline Obs. for 2nd stage & \multicolumn{2}{|c|}{12,797} & \multicolumn{2}{|c|}{11,512} & \multicolumn{2}{|c|}{17,842} \\
\hline Sector dummies & \multicolumn{2}{|c|}{ Yes } & \multicolumn{2}{|c|}{ Yes } & \multicolumn{2}{|c|}{ Yes } \\
\hline Stage of regression & Bribe sought & Got license & Bribe sought & Got license & Bribe sought & Sold to Gov't \\
\hline $\begin{array}{l}\text { Manager is a woman } \\
\text { [dummy] }\end{array}$ & $\begin{array}{l}-0.017 \\
(-0.46)\end{array}$ & $\begin{array}{l}-0.028 * \\
(-1.84)\end{array}$ & $\begin{array}{l}0.130 * * * \\
(2.90)\end{array}$ & $\begin{array}{l}-0.098^{* * *} \\
(-5.84)\end{array}$ & $\begin{array}{l}0.039 \\
(1.14)\end{array}$ & $\begin{array}{l}-0.106^{* * *} \\
(-7.64)\end{array}$ \\
\hline Number of workers & 0.009 & $0.218^{* * *}$ & 0.021 * & $0.169^{* * *}$ & $-0.038^{* * *}$ & $0.112 * * *$ \\
\hline [nat. $\log ]$ & $(0.76)$ & $(53.49)$ & $(1.77)$ & $(38.93)$ & $(-3.96)$ & $(30.04)$ \\
\hline Firm exports & $-0.102^{* * *}$ & $0.106^{* * *}$ & $0.076^{* *}$ & $0.410^{* * *}$ & 0.028 & 0.017 \\
\hline [dummy] & $(-3.28)$ & (7.98) & $(2.06)$ & $(29.94)$ & $(0.96)$ & $(1.33)$ \\
\hline$\%$ foreign-owned & $-0.002 * * *$ & -0.000 & 0.000 & $0.003 * * *$ & $-0.002^{* * *}$ & $-0.001^{* * *}$ \\
\hline [percent] & $(-3.90)$ & $(-1.18)$ & $(0.36)$ & $(13.70)$ & $(-3.89)$ & $(-7.25)$ \\
\hline$\%$ government-owned & -0.003 & $-0.002 * * *$ & -0.001 & -0.000 & -0.001 & $0.004^{* * *}$ \\
\hline [percent] & $(-1.45)$ & $(-3.08)$ & $(-0.33)$ & $(-0.48)$ & $(-0.71)$ & $(6.62)$ \\
\hline Per capita GDP & $-0.282^{* * *}$ & $-0.022 * * *$ & $-0.296^{* * *}$ & $-0.064^{* * *}$ & $-0.131^{* * *}$ & -0.001 \\
\hline [nat. $\log ]$ & $(-19.30)$ & $(-3.50)$ & $(-16.37)$ & $(-9.51)$ & $(-10.87)$ & $(-0.23)$ \\
\hline$\%$ of other firms with license & & $3.913^{* * *}$ & & $4.065^{* * * *}$ & & $3.394^{* * * *}$ \\
\hline [percent] & & $(73.14)$ & & $(87.40)$ & & $(77.89)$ \\
\hline \multirow{2}{*}{ Constant } & $1.617^{* * *}$ & $-2.455^{* * *}$ & $0.910^{* * *}$ & $-2.044^{* * *}$ & 0.061 & $-2.009^{* * *}$ \\
\hline & $(9.88)$ & $(-43.18)$ & $(5.30)$ & $(-32.85)$ & $(0.50)$ & $(-39.73)$ \\
\hline Correlation & \multirow{2}{*}{\multicolumn{2}{|c|}{$\begin{array}{l}0.077^{*} \\
(1.95)\end{array}$}} & \multirow{2}{*}{\multicolumn{2}{|c|}{$\begin{array}{c}0.241 * * * \\
(6.30)\end{array}$}} & \multirow{2}{*}{\multicolumn{2}{|c|}{$\begin{array}{c}0.144^{* * *} \\
(3.67)\end{array}$}} \\
\hline & & & & & & \\
\hline License/gov't interaction & \multicolumn{2}{|c|}{ Operating License } & \multicolumn{2}{|c|}{ Tax Inspection } & & \\
\hline Total observations & \multicolumn{2}{|c|}{99,697} & \multicolumn{2}{|c|}{97,501} & & \\
\hline Obs. for 2nd stage & \multirow{2}{*}{\multicolumn{2}{|c|}{$\begin{array}{c}22,126 \\
\text { Yes }\end{array}$}} & \multirow{2}{*}{\multicolumn{2}{|c|}{$\begin{array}{c}55,676 \\
\text { Yes }\end{array}$}} & & \\
\hline Sector Dummies & & & & & & \\
\hline Stage of Regression & Bribe Sought & Got license & Bribe sought & Inspected & & \\
\hline Manager is female & -0.036 & $0.044^{* * *}$ & 0.007 & $-0.025^{* *}$ & & \\
\hline [dummy] & $(-1.26)$ & $(3.28)$ & $(0.38)$ & $(-2.05)$ & & \\
\hline Number of workers & 0.005 & $0.087^{* * *}$ & $-0.024^{* * *}$ & $0.146^{* * *}$ & & \\
\hline [nat. $\log ]$ & $(0.65)$ & $(22.49)$ & $(-4.39)$ & $(41.56)$ & & \\
\hline Firm exports & $0.045^{*}$ & $0.052 * * *$ & -0.027 & $0.081 * * *$ & & \\
\hline [dummy] & $(1.68)$ & $(4.06)$ & $(-1.52)$ & $(7.10)$ & & \\
\hline$\%$ foreign-owned & $-0.001^{* * *}$ & -0.000 & $-0.001 * * *$ & 0.000 & & \\
\hline [percent] & $(-2.75)$ & $(-0.40)$ & $(-4.61)$ & $(0.97)$ & & \\
\hline$\%$ government-owned & $-0.006^{* * *}$ & -0.000 & 0.000 & $-0.003^{* * *}$ & & \\
\hline [percent] & $(-2.90)$ & $(-0.15)$ & $(0.29)$ & $(-4.74)$ & & \\
\hline Per capita GDP & $-0.215^{* * *}$ & $0.025^{* * *}$ & $-0.251^{* * *}$ & $-0.024 * * *$ & & \\
\hline [nat. $\log ]$ & $(-15.76)$ & $(4.13)$ & $(-28.98)$ & $(-4.49)$ & & \\
\hline$\%$ of other firms with license & & $3.295^{* * *}$ & & $2.891^{* * *}$ & & \\
\hline [percent] & & $(137.71)$ & & $(126.04)$ & & \\
\hline \multirow[t]{2}{*}{ Constant } & $0.747^{* * *}$ & $-2.267^{* * * *}$ & $1.420 * * *$ & $-1.813^{* * *}$ & & \\
\hline & $(6.62)$ & $(-40.27)$ & $(20.60)$ & $(-32.87)$ & & \\
\hline Correlation & \multicolumn{2}{|c|}{$\begin{array}{c}0.089 * * * \\
(4.27)\end{array}$} & & & & \\
\hline
\end{tabular}

Source: Author's calculations based upon data from the World Bank Enterprise Surveys. ${ }^{* * *},{ }^{*}$ Statistically significant at $1 \%, 5 \%$ and $10 \%$ significance levels. Note: t-statistics in parentheses. Observations for second stage are the observations where the firm completed the transaction. Firms that did not complete the transaction were not asked about bribes. The selection variables are dummy variables indicating the firm got a license, sold goods to the government or was inspected by tax officials. For firms that completed that transaction, the dependent variables are dummy variables indicating the firm said bribes were requested or expected during the transaction. The model is a probit model allowing for selection effects. The sector dummies are dummies indicating the firm is in manufacturing, services, or retail trade.

\subsection{Main Results}

Effect of Gender on Probability of Interacting with the Government. The results in Table 4 mostly support the first hypothesis, which states that firms with women in positions of power are less likely to interact with government officials than firms with men in similar positions. Female-managed firms were less likely to get construction and import licenses, meet with tax officials, and sell goods or services to the government than other firms. The dummies' coefficients were all negative and significant. In contrast, female-managed firms were more likely to get operating licenses than other firms. Operating licenses might be 
different because the formal firms in the WBES cannot avoid them; in contrast, they can choose not to bid on government contracts or get import or construction licenses. Although avoiding tax inspections might also be difficult, firms could hire professional accountants or be more conservative when paying taxes to do so.

The differences, however, are modest (see Table 5). The likelihood the average firm would get a construction license would be 0.5 percentage points lower if the firm had a female rather than male manager. Similarly, the difference was about 0.8 percentage points for meetings with tax officials and about 1.5 percentage points for getting import licenses. The biggest difference is for government sales; the average firm would be 2.4 percentage points less likely to sell goods and services to the government if it had a woman manager. Since fewer than one-fifth of firms sold goods or services to the government, this difference is large.

Table 5. Probability of paying bribe.

\begin{tabular}{ccccccc}
\hline & \multicolumn{3}{c}{ Ave. Prob. of Transaction } & \multicolumn{2}{c}{ Cond. Prob of Bribe } \\
\hline & Men & Women & Diff. & Men & Women & Diff. \\
\hline Construction License & $12.8 \%$ & $12.3 \%$ & $-0.5 \%$ & $22.2 \%$ & $21.8 \%$ & $-0.4 \%$ \\
Import License & $11.7 \%$ & $10.2 \%$ & $-1.5 \%$ & $12.3 \%$ & $15.5 \%$ & $3.3 \%$ \\
Sales to Government & $18.3 \%$ & $15.8 \%$ & $-2.4 \%$ & $15.7 \%$ & $17.0 \%$ & $1.3 \%$ \\
Operating License & $21.9 \%$ & $22.9 \%$ & $1.0 \%$ & $14.9 \%$ & $14.0 \%$ & $-0.9 \%$ \\
Meetings with Tax Officials & $57.2 \%$ & $56.4 \%$ & $-0.8 \%$ & $11.5 \%$ & $11.5 \%$ & $0.0 \%$ \\
\hline \multicolumn{7}{c}{ Average Prob. of Bribe } \\
\hline Men & Women & Diff. & & & \\
\hline Construction License & $2.60 \%$ & $2.44 \%$ & $-0.16 \%$ & & & \\
Import License & $1.29 \%$ & $1.42 \%$ & $0.13 \%$ & & & \\
Sales to Government & $2.73 \%$ & $2.54 \%$ & $-0.18 \%$ & & & \\
Operating License & $3.18 \%$ & $3.13 \%$ & $-0.05 \%$ & & & \\
Meetings with Tax Officials & $7.46 \%$ & $7.41 \%$ & $-0.05 \%$ & & & \\
\hline
\end{tabular}

Including a dummy for fully female-owned firms instead of a dummy for femalemanaged firms gives similar results (see Table 6). Female-owned firms were less likely to apply for import licenses, sell goods to the government, or meet with tax officials than other firms. Additionally, like female-managed firms, female-owned firms were more likely to have applied for operating licenses than other firms.

Compared with the results for female managers and owners, the results for female respondents are even more supportive of the first hypothesis. Female respondents were less likely to say their firms applied for licenses, including operating licenses, sold goods or services to the government, and met with tax officials than male respondents.

Effect of Gender on Probability of Paying a Bribe During Interactions. In contrast, the results in Table 4 do not support the second hypothesis, which suggests that women will be less likely to pay bribes when they do interact with government officials. Firms with female managers were neither more nor less likely to pay bribes than male managers when they met with officials; the coefficients were insignificant in most second-stage regressions. Further, the coefficients' signs are not consistent across regressions; they are positive in three cases and negative in two. The one significant coefficient is for import licenses. Female managers were more likely than male managers to say officials sought bribes when getting import licenses. 
Table 6. Coefficients on gender variables in robustness checks.

\begin{tabular}{|c|c|c|c|c|c|c|}
\hline \multirow{2}{*}{$\begin{array}{c}\text { License/gov't Interaction } \\
\text { Stage of regression }\end{array}$} & \multicolumn{2}{|c|}{ Construction License } & \multicolumn{2}{|c|}{ Import License } & \multicolumn{2}{|c|}{ Sales to Government } \\
\hline & Bribe Sought & Got License & Bribe Sought & Got License & Bribe Sought & Sold to Gov't \\
\hline \multicolumn{7}{|l|}{ Base Model } \\
\hline Manager is a woman & -0.017 & $-0.028 *$ & $0.130^{* * *}$ & $-0.098^{* * *}$ & 0.039 & $-0.106^{* * *}$ \\
\hline All owners are women & -0.020 & 0.026 & $0.243^{* * *}$ & $-0.065^{* *}$ & $0.101^{*}$ & $-0.064^{* * *}$ \\
\hline Respondent is a woman & $-0.135 * * *$ & $-0.098^{* * *}$ & -0.019 & $-0.097^{* * *}$ & $-0.103 * * *$ & $-0.112 * * *$ \\
\hline \multicolumn{7}{|l|}{ Gender vars. simultaneously } \\
\hline Manager is a woman & 0.001 & -0.025 & $0.208^{* * *}$ & -0.018 & $0.117 * *$ & -0.030 \\
\hline All owners are women & 0.066 & $0.065 * *$ & $0.195 * *$ & -0.033 & 0.096 & -0.039 \\
\hline Respondent is a woman & $-0.182 * * *$ & $-0.062 * * *$ & $-0.128 * *$ & $-0.050 * *$ & $-0.102 * *$ & -0.020 \\
\hline \multicolumn{7}{|l|}{$\begin{array}{l}\text { Countries with low } \\
\text { corruption }\end{array}$} \\
\hline Manager is a woman & 0.090 & $-0.053 * *$ & $0.352 * * *$ & $-0.101 * * *$ & 0.073 & $-0.077^{* * *}$ \\
\hline All owners are women & 0.168 & -0.036 & 0.209 & -0.090 & -0.084 & $-0.088 * *$ \\
\hline Respondent is a woman & -0.008 & $-0.091^{* * *}$ & 0.034 & $-0.086^{* * *}$ & -0.051 & $-0.061^{* * *}$ \\
\hline \multicolumn{7}{|l|}{$\begin{array}{l}\text { Countries with high } \\
\text { corruption }\end{array}$} \\
\hline Manager is a woman & -0.071 & $-0.055 *$ & -0.021 & $-0.100 * * *$ & 0.007 & $-0.156^{* * *}$ \\
\hline All owners are women & -0.024 & 0.034 & 0.102 & -0.029 & 0.026 & -0.034 \\
\hline Respondent is a woman & $-0.262 * * *$ & $-0.120^{* * *}$ & -0.064 & $-0.139 * * *$ & $-0.260 * * *$ & $-0.162^{* * *}$ \\
\hline \multicolumn{7}{|l|}{ Country and sector dummies } \\
\hline Manager is a woman & -0.051 & -0.001 & 0.011 & $-0.087^{* * *}$ & 0.029 & $-0.048^{* * *}$ \\
\hline All owners are women & -0.037 & 0.018 & 0.130 & $-0.085^{* * *}$ & 0.013 & -0.018 \\
\hline Respondent is a woman & $-0.181^{* * *}$ & $-0.113^{* * *}$ & $-0.125^{* * *}$ & $-0.092 * * *$ & $-0.162 * * *$ & $-0.105^{* * *}$ \\
\hline \multicolumn{7}{|l|}{ Sales Included } \\
\hline Manager is a woman & -0.008 & -0.014 & $0.111 * *$ & $-0.081 * * *$ & 0.028 & $-0.088^{* * *}$ \\
\hline All owners are women & -0.030 & 0.036 & $0.183 * *$ & -0.028 & 0.082 & -0.041 \\
\hline Respondent is a woman & $-0.122 * * *$ & $-0.067^{* * *}$ & -0.005 & $-0.083^{* * *}$ & $-0.106^{* * *}$ & $-0.095^{* * *}$ \\
\hline License/gov't Interaction & \multicolumn{2}{|c|}{ Construction License } & \multicolumn{2}{|c|}{ Tax Inspection } & & \\
\hline Stage of Regression & Bribe Sought & Got License & Bribe Sought & Inspected & & \\
\hline Base Model & & & & & & \\
\hline Manager is a woman & -0.036 & $0.044^{* * *}$ & 0.007 & $-0.025^{* *}$ & & \\
\hline All owners are women & $-0.096 * *$ & $0.076^{* * *}$ & -0.010 & $-0.041 * *$ & & \\
\hline Respondent is a woman & $-0.161^{* * *}$ & $-0.053^{* * *}$ & $-0.099 * * *$ & $-0.079 * * *$ & & \\
\hline \multicolumn{7}{|l|}{ Gender vars. simultaneously } \\
\hline Manager is a woman & $0.155^{* * *}$ & $0.081 * * *$ & $0.114^{* * *}$ & 0.025 & & \\
\hline All owners are women & -0.072 & $0.069 * *$ & 0.003 & -0.024 & & \\
\hline Respondent is a woman & $-0.246^{* * *}$ & $-0.074^{* * *}$ & $-0.162^{* * *}$ & $-0.066^{* * *}$ & & \\
\hline \multicolumn{7}{|l|}{$\begin{array}{l}\text { Countries with low } \\
\text { corruption }\end{array}$} \\
\hline Manager is a woman & $0.154^{* *}$ & $0.050 * *$ & 0.021 & -0.025 & & \\
\hline All owners are women & 0.148 & $0.123^{* * *}$ & 0.012 & 0.056 & & \\
\hline Respondent is a woman & -0.011 & $-0.047^{* *}$ & -0.045 & $-0.066^{* * *}$ & & \\
\hline \multicolumn{7}{|l|}{$\begin{array}{l}\text { Countries with high } \\
\text { corruption }\end{array}$} \\
\hline Manager is a woman & -0.059 & 0.012 & -0.030 & -0.027 & & \\
\hline All owners are women & -0.039 & $0.064 *$ & -0.032 & -0.041 & & \\
\hline Respondent is a woman & $-0.111^{* * *}$ & $-0.038 *$ & $-0.172 * * *$ & $-0.053^{* * *}$ & & \\
\hline \multicolumn{7}{|l|}{ Country and sector dummies } \\
\hline Manager is a woman & -0.043 & $0.052 * * *$ & -0.004 & -0.017 & & \\
\hline All owners are women & -0.066 & 0.056 ** & -0.017 & $-0.046^{* *}$ & & \\
\hline Respondent is a woman & $-0.155^{* * *}$ & $-0.053 * * *$ & $-0.131^{* * *}$ & $-0.069 * * *$ & & \\
\hline \multicolumn{7}{|l|}{ Sales Included } \\
\hline Manager is a woman & -0.034 & $0.038^{* * *}$ & 0.000 & $-0.022 *$ & & \\
\hline All owners are women & $-0.113 * *$ & $0.058 * *$ & -0.027 & -0.029 & & \\
\hline Respondent is a woman & $-0.165^{* * *}$ & $-0.048^{* * *}$ & $-0.099^{* * *}$ & $-0.061^{* * *}$ & & \\
\hline
\end{tabular}

Source: Author's calculations based upon data from the World Bank Enterprise Surveys. ${ }^{* * *},{ }^{* *}, *$ Statistically significant at $1 \%, 5 \%$, and $10 \%$ significance levels. Note: $t$-statistics in parentheses. Observations for second stage are the observations where the firm completed the transaction. Firms that did not complete the transaction were not asked about bribes. The selection variables are dummy variables indicating the firm got a license, sold goods to the government, or was inspected by tax officials. For firms that completed that transaction, the dependent variables are dummy variables indicating the firm said bribes were requested or expected during the transaction. The model is a probit model allowing for selection effects. The regressions include all control variables listed in Table 4 except as noted. Full regression results are available in an online only Supplementary Materials (Tables S3-S17). 
The results for female owners also fail to support the second hypothesis. In the secondstage bribe regressions, three of five coefficients were significant-more than the single significant coefficient for female-managed firms. However, as for female-managed firms, the coefficients' signs were inconsistent across transactions.

In contrast to female managers and owners, the results for female respondents support the second hypothesis. Female respondents were less likely than male respondents to say officials asked for bribes during meetings. Moreover, four of five coefficients are significant at a 1 percent level or higher.

\subsection{Breakdown by Level of Corruption}

To see whether female-dominated firms behave differently in the most and least corrupt countries, we ran separate regressions for the two groups (see Table 6). We did this because Esarey and Chirillo (2013) find women tolerate corruption less than men only in countries with stronger democratic institutions. We classified countries based on their score on the World Governance Indicators' Control of Corruption indicator (Kaufmann et al. 2009). We used this external measure, rather than an internal measure based on WBES data, to reduce concern about endogeneity.

The results are similar for the two groups. For example, female-managed firms were less likely to apply for construction and import licenses and sell goods and services to the government than male-managed firms in both. The negative coefficients are significant in all six first-stage regressions. Both coefficients are also negative, although insignificant, for meetings with tax officials. Finally, female-managed firms were significantly more likely to get operating licenses than male-managed firms in only the most corrupt countries.

Female managers were neither more nor less likely to say officials sought bribes than male managers in the most corrupt countries; the dummy's coefficients are usually insignificant. In contrast, female managers appear more likely to say officials sought bribes in less corrupt countries; all coefficients are positive-although only two are significant.

The results for female owners and respondents are also similar in the two groups. Female respondents were less likely to say they met with tax officials, got licenses, or sold to the government in both groups of countries. Similarly, the coefficients on the ownership dummy are insignificant in most regressions for owners. The biggest difference between highly and less corrupt countries is female respondents were less likely to say officials sought bribes only in very corrupt countries.

\subsection{Robustness Checks}

Model Specification. The results support the idea that we need to control for selection in the empirical analysis. Firms are more likely to meet with government officials and sell government goods and services when other firms in the same city do. The leave-one-out average that helps to identify the model is positive and significant in all regressions. The two error terms are correlated, suggesting it is fitting to allow for selection.

Including all gender dummies. All gender dummies were included in a single regression as a final exercise. As noted earlier, the correlation between the three dummies is high, but not perfect. Female-managed firms are more likely to have female owners and respondents than male-managed firms. Multicollinearity, therefore, might make it difficult to include all three dummies simultaneously.

When we include all three at the same time, the strongest results are for respondents (see Table 6). Female respondents remain less likely to report their firms got licenses, sold goods to the government, or met with tax officials than were male respondents. They were also less likely to say officials requested bribes during these meetings. The coefficients on the respondent dummy were significant in nine of ten cases.

In contrast, after controlling for the respondent's gender, female-managed and -owned firms were no longer less likely to interact with government officials than other firms. The coefficients on the manager and owner dummies are positive or insignificant after controlling for the respondent's gender. Moreover, female-managed firms were more, not 
less, likely to say officials asked for bribes after controlling for the respondent's gender. These findings support the earlier observation that results are more uniform and significant for female respondents than for female managers and owners.

Extra Dummies. The base model includes three industry dummies and per capita GDP to control for different licensing rules across industries and countries. As a robustness check, we include more industry dummies-20 in total—and country-year dummies to control for differences between industries and countries.

The results for female managers are similar to-but weaker than-the results from the base model (see Table 6). Female-managed firms remain less likely to get construction and import licenses, sell to the government, and meet with tax inspectors than malemanaged firms. The coefficients, however, are only significant twice: for import licenses and government sales. They also remain more likely to try to get operating licenses than other firms. In contrast, the dummy's coefficients are insignificant in all bribe regressions. Overall, the results suggest female-managed firms are less likely to interact with government officials than male-managed firms but do not support the idea that officials are less likely to ask female-managed firms for bribes.

The extended model's results for female-owned firms are also similar but weaker than the base model's results. Female-owned firms were less likely to get import licenses and meet with tax inspectors but more likely to get operating licenses than other firms. The coefficient becomes insignificant, however, for construction licenses and government sales. All coefficients are insignificant in the extended model's second-stage bribe regressions.

Finally, the results for female respondents are also similar to the base model results. In contrast to the female-managed and -owned firms' results, however, results for female respondents are as strong in the extended model as in the base model. The dummy's coefficients remain negative and significant in both transaction and bribe regressions. Female respondents were less likely to say they met with officials or applied for licenses and to say officials asked for bribes during meetings than male respondents.

Sales. The base model includes the number of workers to control for firm size. We could, however, control for size using sales instead. The most notable disadvantage of using sales is the sample becomes 8 to 9 percent smaller when we do. This is not surprising; firms are often reluctant to report financial data (Iarossi 2006).

The results using sales are similar to the base results for female managers and respondents. Female-managed firms are less likely to get import licenses, sell to the government, and meet with tax officials and are more likely to get operating licenses than male-managed firms. For the bribe regressions, most coefficients remain insignificant. The results for female respondents are also similar in size and significance to the base model's results.

In contrast, the results for female owners are weaker when we include sales rather than workers. The female owner dummy's coefficients are insignificant in four of five regressions for both transactions and bribes. The results that include sales do not support the idea that female-owned firms are different from other firms.

\section{Discussion}

When women can influence firm behavior, firms interact less with government officials when they can. For example, female-managed firms are less likely to apply for construction and import licenses and sell goods and services to the government than male-managed firms. When they find it tougher to avoid interacting with officials, this is no longer always true; female-managed firms are more, not less, likely to apply for operating licenses. These results are consistent with the paper's first hypothesis.

Firms with more substantial female participation might interact less with government officials than other firms for several reasons. Women might avoid bureaucrats because, on average, they are more risk-averse, dislike bargaining more, or because they are more honest than men. Alternatively, they might avoid corrupt officials because they are less likely to belong to the insider networks that would allow them to bribe those officials. 
In contrast, the results do not support the paper's second hypothesis. Women were no less likely to report officials asked for or expected bribes during meetings than men. In fact, female managers were more, not less, likely to say government representatives wanted bribes than male managers when the differences were significant. Results for female-owned firms are similar; female-owned firms were significantly more likely to say bureaucrats sought bribes than other firms in two cases and significantly less likely in only one. In contrast, female respondents were less likely to say officials asked for bribes in all cases.

The results broadly support the hypothesis that female managers and owners are more averse to paying bribes than men and avoid doing so by limiting how often they meet with government officials. Some results, however, appear anomalous. First, female-managed firms are less likely to get construction and import licenses and to bid on government contracts than male-managed firms in both the most and least corrupt countries. If female managers and owners avoid meeting officials because they dislike paying bribes, we might expect them to avoid meetings more actively in very corrupt countries than in less corrupt countries. In countries where bribe demands are rare, female managers have less reason to avoid government officials. Because we do not observe women interacting more with officials in less corrupt countries than in extremely corrupt countries, this might suggest female managers avoid officials for other reasons.

Second, it is not clear why the differences between firms with male and female respondents are more substantial than the differences between female-managed and owned firms and male-managed and -owned firms. Although firms with female managers and owners were less likely to meet with government officials than other firms, they were no less likely to report requests for bribes during these meetings. In contrast, female respondents were less likely to report bribe demands than male respondents. Moreover, the difference between male and female respondents is larger and more significant than for male- and female-managed and -owned firms. This seems odd given the manager's and owner's gender should affect firm behavior more than the gender of the person selected to answer the survey.

One way to explain why female respondents report fewer meetings and bribe demands than male respondents is that female respondents might be more likely to misreport their firm's behavior. Like other sensitive topics, people often lie about bribes (Azfar and Murrell 2009; Clausen et al. 2010; Recanatini et al. 2000). Indeed, most surveys use indirect questions about corruption because survey designers hope indirect questions will elicit more honest answers than direct questions. If women misreport bribe demands more often than men-possibly because they worry more about social desirability-the gender of the person answering the questions might matter more than the manager's or owner's gender.

Although it is difficult to know whether women misreport bribe payments more often than men, some evidence suggests they might. The best evidence on lying about bribes is from papers about reticent respondents. Clausen et al. (2010) and Karalashvili et al. (2015) find reticent respondents lie both about meeting with officials and paying bribes during the meetings. Although Azfar and Murrell (2009) and Clausen et al. (2010) find Romanian and Nigerian women are more reticent than men, the differences are not significant. In contrast, Clarke (2020), who used a larger sample from nine surveys in six countries, found women are more reticent than men.

The results in this paper have interesting implications for firms and policy makers. First, the results are consistent with previous research that shows that female-managed and -owned firms are less likely to pay bribes than similar male-dominated firms. Encouraging female ownership and management might, therefore, be a useful way to reduce corruption.

The results also suggest that corruption might be a greater constraint for female-owned and -managed firms than it is for other firms. Female-owned and -managed firms appear to avoid paying bribes by avoiding meeting with government officials and by not applying for licenses. This, however, might restrict the growth of these firms. For example, if femaleowned firms do not apply for import and export licenses because of corruption, these firms 
might find it harder to grow and improve their productivity. Reducing corruption might therefore increase opportunities for women.

Finally, the results suggest the need for additional research related to ethics, women, and corruption. If women are less likely to pay bribes than men, they might also behave more ethically in other ways. For example, they might be less likely to evade taxes or comply with important regulations.

Further research might also provide greater information on the link between bribery and gender. The second question's phrasing means it is difficult to know whether femalemanaged or -owned firms pay more bribes than other firms. Researchers often implicitly or explicitly assume that when firms say that firms like theirs pay bribes or say that officials asked them for bribes, the firm paid a bribe. If we assumed this, it would imply femalemanaged and -owned firms were no less likely—and possibly more likely—to pay bribes than other firms. If female managers were more honest than male managers, we would not expect this; we would expect female-managed firms to pay bribes less often than male-managed firms.

However, if we interpret the question literally, we could only infer that officials target female-managed or -owned firms. Officials might do this if they believe women will haggle less than men over the amount or need for a bribe. Even if officials focus on femalemanaged and -owned firms, many might refuse to pay. Female managers or owners might refuse if they were more honest than their male counterparts. Without more information, we cannot test this hypothesis. Given the mixed evidence on whether indirect questions extract honest answers (Clarke et al. 2015), more direct and easier to interpret questions about bribes would improve what we know about gender and corruption.

A second way to expand this research would be to collect better evidence on the relationship between reticence and gender. As noted above, this would allow us to better understand the links between gender and corruption. Collecting information on reticence would allow researchers to explore the possibility that the link between gender and corruption is due to women underreporting bribe payments. Using more sophisticated approaches to getting honest answers-or identifying untruthful respondents (Azfar and Murrell 2009; Clausen et al. 2010) —might further improve what we know about corruption and gender.

Supplementary Materials: The following are available online at https:/ /www.mdpi.com/2227-709 9/9/1/19/s1, Table S1: List of Countries with data on female managers, Table S2: Sample means of dependent and independent variables, Table S3: Probability that firms engage with government and that bribe was requested, female owners, Table S4: Probability that firms engage with government and that bribe was requested, female respondents, Table S5: Probability that firms engage with government and that bribe was requested, all female variables, Table S6: Probability that firms engage with government and that bribe was requested in countries with low corruption, managers, Table S7: Probability that firms engage with government and that bribe was requested in countries with low corruption, owners, Table S8: Probability that firms engage with government and that bribe was requested in countries with low corruption, respondents, Table S9: Probability that firms engage with government and that bribe was requested in countries with high corruption, managers, Table S10: Probability that firms engage with government and that bribe was requested in countries with high corruption, owners, Table S11: Probability that firms engage with government and that bribe was requested in countries with high corruption, respondents, Table S12: Probability that firms engage with government and that bribe was requested with country and sector dummies included, managers, Table S13: Probability that firms engage with government and that bribe was requested with country and sector dummies included, female owners, Table S14: Probability that firms engage with government and that bribe was requested with country and sector dummies, female respondents, Table S15: Probability that firms engage with government and that bribe was requested with sales included, female manager, Table S16: Probability that firms engage with government and that bribe was requested with sales included, female owners, Table S17: Probability that firms engage with government and that bribe was requested with sales included, female respondents.

Funding: This research received no external funding. 
Data Availability Statement: The data used in this paper are available from the Enterprise Surveys (http:/ / www.enterprisesurveys.org), The World Bank.

Conflicts of Interest: The authors declare no conflict of interest.

\section{References}

Alatas, Vivi, Lisa Cameron, Ananish Chaudhuri, Nisvan Erkal, and Lata Gangadharan. 2009. Gender, culture and corruption: Insights from an experimental analysis. Southern Economic Journal 75: 663-80.

Azfar, Omar, and Peter Murrell. 2009. Identifying reticent respondents: Assessing the quality of survey data on corruption and values. Economic Development and Cultural Change 57: 387-411. [CrossRef]

Bertrand, Marianne, Simeon Djankov, Rema Hanna, and Sendhil Mullainathan. 2007. Obtaining a driver's license in India: An experimental approach to studying corruption. Quarterly Journal of Economics 122: 1639-76. [CrossRef]

Bossuyt, Saar, and Patrick Van Kenhove. 2018. Assertiveness bias in gender ethics research: Why women deserve the benefit of the doubt. Journal of Business Ethics 150: 727-39. [CrossRef]

Breen, Michael, Robert Gillanders, Gemma McNulty, and Akisato Suzuki. 2017. Gender and corruption in business. Journal of Development Studies 53: 1486-501. [CrossRef]

Britton, Dana, Shannon Jacobsen, and Grace Howard. 2018. The Gender of Crime. Lanham: Rowman and Littlefield.

Clarke, George RG. 2020. Are Women More Reticent than Men. Laredo: Texas A\&M International University.

Clarke, George RG, and Lixin Colin Xu. 2004. Privatization, competition and corruption: How characteristics of bribe takers and payers affect bribes to utilities. Journal of Public Economics 88: 2067-97. [CrossRef]

Clarke, George RG, Klaus S. Friesenbichler, and Michael Wong. 2015. Do indirect questions reduce lying about corruption? Evidence from a quasi-field experiment. Comparative Economic Studies 57: 103-35. [CrossRef]

Clausen, Bianca, Aart Kraay, and Peter Murrell. 2010. Does Respondent Reticence Affect the Results of Corruption Surveys? Evidence from the World Bank Enterprise Survey for Nigeria. Policy Research Working Paper No. 5415. Washington, DC: World Bank.

Croson, Rachel, and Uri Gneezy. 2009. Gender difference in preferences. Journal of Economic Literature 47: 448-74. [CrossRef]

de Soto, Hernando. 1988. The Other Path. New York: Basic Books.

Debski, Julia, Michael Jetter, Saskia Mösle, and David Stadelmann. 2018. Gender and corruption: The neglected role of culture. European Journal of Political Economy 55: 526-37. [CrossRef]

Dollar, David, Raymond Fisman, and Roberta Gatti. 2001. Are women really the 'fairer' sex? Corruption and women in government. Journal of Economic Behavior and Organization 46: 423-29. [CrossRef]

Esarey, Justin, and Gina Chirillo. 2013. "Fairer sex" or purity myth? Corruption, gender, and institutional context. Politics and Gender 9: 361-89. [CrossRef]

Federal Bureau of Investigations. 2018. Uniform Crime Report: Crime in the United States; Washington, DC: Federal Bureau of Investigations.

Frank, Björn, Johann Graf Lambsdorff, and Frédéric Boehm. 2011. Gender and corruption: Lessons from laboratory corruption experiments. European Journal of Development Research 23: 59-71. [CrossRef]

Goetz, Anne Marie. 2007. Political cleaners: Women as the new anti-corruption force? Development and Change 38: 87-105. [CrossRef]

Graf Lambsdorff, Johann, and Hady Fink. 2006. Combatting Corruption in Colombia: Perceptions and Achievements. Passauer Dikussionspapiere No. 44-06. Passau: University of Passau.

Hofstede, Geert. 1984. Culture's Consequences, International Differences in Work-Related Values. Newbury Park: Sage Publications.

Iarossi, Giuseppe. 2006. The Power of Survey Design. Washington, DC: World Bank.

Johnson, Simon, John McMillan, and Christopher Woodruff. 2002. Property rights and finance. American Economic Review 92: 1335-56. [CrossRef]

Karalashvili, Nona, Aart Kraay, and Peter Murrell. 2015. Doing the Survey Two-Step: The Effects of Reticence on Estimates of Corruption in Two-Stage Survey Questions. Policy Research Working Paper No. 7276. Washington, DC: World Bank.

Kaufmann, Daniel, Aart Kraay, and Massimo Mastruzzi. 2009. Governance Matters VIII: Governance Indicators for 1996-2008. Policy Research Working Paper No. 4978. Washington, DC: World Bank.

Mocan, Naci. 2008. What determines corruption? International evidence from microdata. Economic Inquiry 46: 493-510. [CrossRef]

O'Fallon, Michael J., and Kenneth D. Butterfield. 2005. A review of the empirical decision-making literature: 1996-2003. Journal of Business Ethics 59: 375-413. [CrossRef]

Recanatini, Francesca, Scott Wallsten, and Lixin Colin Xu. 2000. Surveying Surveys and Questioning Questions: Learning from World Bank Experience. Policy Research Working Paper No. 2307. Washington, DC: World Bank.

Rivas, M. Fernanda. 2013. An experiment on corruption and gender. Bulletin of Economic Research 65: 10-42. [CrossRef]

Ross, Lee, David Greene, and Pamela House. 1977. The 'false consensus effect': An egocentric bias in social perception and attribution processes. Journal of Experimental Social Psychology 13: 279-301. [CrossRef]

Shah, Manju Kedia. 2012. The Informal Sector in Zambia: Can it Disappear? Should it Disappear? IGC Working Paper No. 12/0425. London: International Growth Center.

Shurchkov, Olga, and Catherine C. Eckel. 2018. Gender differences in behavioral traits and labor market outcomes. In Oxford Handbook on Women and the Economy. Edited by Susan Averett, Laura Argys and Saul Hoffman. Oxford: Oxford University Press, pp. 481-512. 
Sung, Hung-En. 2003. Fairer sex of fairer system? Gender and corruption revisited. Social Forces 82: 703-23. [CrossRef]

Svensson, Jakob. 2003. Who must pay bribes and how much? Evidence from a cross section of firms. Quarterly Journal of Economics 118: 207-30. [CrossRef]

Swamy, Anand, Stephen Knack, Young Lee, and Omar Azfar. 2001. Gender and corruption. Journal of Development Economics 64: 25-55. [CrossRef]

Torgler, Benno, and Neven T. Valev. 2010. Gender and public attitudes toward corruption and tax evasion. Contemporary Economic Policy 28: 554-68. [CrossRef]

Ufere, Nnaoke, Sheri Perelli, Richard Boland, and Bo Carlsson. 2012. Merchants of corruption: How entrepreneurs manufacture and supply bribes. World Development 40: 2440-53. [CrossRef]

United Nations Office on Drugs and Crime. 2013. Global Homicide Study. Vienna: United Nations Office on Drugs and Crime.

Walmsley, Roy. 2017. World Female Imprisonment List. London: Institute for Criminal Policy Research.

World Bank. 2006. Enterprise Survey: Screener Questionnaire. Washington, DC: World Bank.

World Bank. 2007. World bank's Enterprise Surveys: Understanding the Questionnaire. Washington, DC: World Bank. 